\title{
Observed Effects of Warm Season Perennial Grass Agriculture on Resident Mammal Species
}

\author{
David D. Leimbach $^{1} \&$ Gregg J. Marcello ${ }^{1}$ \\ ${ }^{1}$ Department of Biology, Millikin University, Decatur, Illinois, 62526, USA \\ Correspondence: David D. Leimbach, 4560 Butler Drive, Decatur, Illinois, 62526. USA. Tel: 1-217-853-9769. \\ E-mail: dleimbach@millikin.edu
}

Received: March 5, 2015 Accepted: March 26, 2015 Online Published: April 3, 2015

doi:10.5539/sar.v4n2p70 URL: http://dx.doi.org/10.5539/sar.v4n2p70

\begin{abstract}
This study focused on the observed impact of switching from a corn / soybean agricultural rotation to the planting of warm season perennial grasses for use in biomass agriculture, as well as the subsequent effects on resident mammal populations. We trapped two parcels of land planted in warm season perennial grasses between September 2011 and October 2013 in order to obtain a census of the mammal populations residing upon the property and to determine the impact (if any) of the change in agriculture. During the first year of the study, a seemingly inhospitable (urban) agricultural area revealed a diverse population of inhabitants. The second year of trapping resulted in the capture of 2 new species (total of 7 species captured) and the noticeable absence of 1 species; a distinct shift in mammal populations had been observed. There was an inverse relationship between the population increase of Peromyscus maniculatus during 2012 and the decline in the population of Peromyscus leucopus. When a Chi-square test was run $(P<0.05)$, the hypothesis of competitive exclusion appeared to be supported. In the third year, population numbers of Peromyscus maniculatus had also plummeted. We observed that warm season perennial grass monoculture had an adverse impact on resident mammal species.
\end{abstract}

Keywords: perennial grasses, rotation vs. biomass agriculture, small mammals, sustainable agriculture

\section{Introduction}

Soil erosion is a worldwide concern with devastating consequences including: desertification of land and pollution of fresh water sources (Brown, 2011). Removal of natural barriers to protect against soil erosion from entering into the watershed is a major concern in Central Illinois. Soil erosion can be combatted by planting a hearty variety of warm season perennial grasses such as Panicum virgatum (switchgrass) on marginal ground (ground with little value agriculturally, traditionally found along creek banks, stream borders and other natural water shed areas) as a riparian buffer. The deep root systems of native grasses hold soil in place, reducing erosion which keeps waterways healthy (Ryan \& Marks, 2005). Switchgrass (as well as other cool and warm season grasses planted) can provide cover for animals, forage for ungulates and habitat for nesting birds and various mammals, all while protecting waterways. Perennial grass based agriculture has the potential to limit runoff of nitrates and phosphate as a result of agricultural production methods, all while providing structure and cover for organisms in the community.

Warm season perennial grasses (P. virgatum, Sorghastrum nutans and Andropogon gerardii, etc.) as well as exotic grass species (such as Miscanthus $x$. giganteus), have been identified as a possible bio-mass based agricultural crop for use in cellulosic ethanol production, as a household heating source and as an additive in coal fired electrical generating plants. Due to the removal of millions of acres of marginal ground from the Conservation Reserve Program (CRP), corn and soybean production is expected to rise and damage to the environment as a result of increased agricultural production is also expected to rise (John \& Watson, 2007). It is the desire of numerous environmental entities (John \& Watson, 2007) for marginal ground removed from the CRP to be converted into biomass agricultural production areas to protect the riparian waterways.

The Conservation Reserve Program, as we know it today, began in 1985 as part of the Food Security Act enacted by the United States Congress (Hartman et al., 2011). The CRP provides monetary reimbursement to landowners for retiring or removing land from agricultural production (Hartman et al., 2011). At the beginning of 2007, 34.7 million acres of marginal ground were enrolled in the CRP, which had a capped enrollment of 39 million acres. By 2017, due to a lowering of the enrollment cap by the United States Congress, 14 million acres formerly in the 
CRP will have been dis-enrolled and returned to traditional agricultural production. A downfall to the conservation reserve program is that farmers are unable to harvest any material from the CRP ground. Should the subsidy for CRP get abolished by law, the affected farmers will revert the former CRP ground into an agricultural production area with a normal rotation of corn or soybeans. The increased agricultural production will in turn lower grain prices because of over-abundance, raise costs of consumer items because of increased fuel and equipment costs, increase soil erosion and at the same time, result in a loss of wildlife habitat and biodiversity (Batie, 2009).

While there is little doubt that warm season perennial grasses are beneficial for the environment, the extent of the benefit of biomass based monocultures in an agricultural setting is questionable. In order to maximize the potential of bio-mass based agriculture, the production of bio-mass based agricultural products must be economically viable for farmers and there must be a sustainable market in Illinois for the end consumption of the product. Historically, perennial grass agricultural strategies have been planned and implemented similar to traditional production agriculture, in monoculture ecosystems (Hartman et al., 2011). When grown in large monocultures, research has shown that $P$. virgatum has an increased susceptibility to some strains of the yellow barley dwarf virus (Hartman et al., 2011) and researchers suggest that any Conservation Reserve Program (CRP) land converted to biofuel production should focus on a combination of warm and cool season grasses to maximize the potential benefits for wildlife (Hartman et al., 2011).

Millikin University was contacted by the Agricultural Watershed Institute (AWI) to conduct a third party collaboration research study. The AWI was in need of a survey of birds, arthropods and mammals occupying a parcel of property owned by CAT. The AWI and CAT have invested in planting several varieties of warm season perennial grasses to be used as a bio-mass crop in lieu of a normal corn / soybean rotation. Because of the elimination of millions of acres from the CRP, AWI wanted to know if bio-mass production is a viable alternative (i.e. profitable) when compared to corn and soybeans. If it was found to be profitable and competitive, they hoped to petition congress to underwrite the initial cost of planting warm season perennial grasses on former CRP ground for farmers. In this respect, current CRP ground could be planted in warm season perennial grasses and farmers could possibly be allowed to harvest the bio-mass acreage to subsidize their income at a reduced cost to taxpayers. Caterpillar, Inc. (CAT)., as an agricultural machinery producer, was interested in knowing the results of this study on bio-mass, as well as knowing what animals currently reside on the bio-mass production ground.

We spent the late-summer and fall of 2011 through 2013 studying the habitat use and population characteristics of mammals located on two tracts of farm ground at the CAT research site in Decatur, Illinois. The site had been planted in warm season perennial grasses, including: P. virgatum, A.gerardii and S. nutans. We hypothesized early on that mammal populations would be small or even absent completely from the research area due to: a lack of natural travel corridors, a lack of an available water source, no substantial shelter in the research area larger than 1 meter tall, and the fact that the research area is a veritable island within an urban environment. The intent of our study was to capture and catalog mammals residing on the research grounds and determine the impact of switching from traditional corn/soybean agriculture to warm season perennial grasses on mammals.

\section{Method}

\subsection{Study Site}

In a collaborative effort between Millikin University, AWI and CAT, we trapped two parcels of ground on the

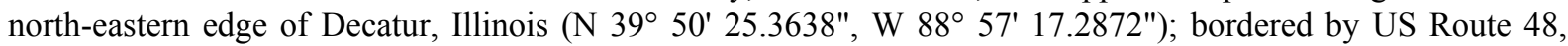
Illinois Route 121 and the Caterpillar, Inc. property. The site is bisected by a local road and is in two parcels. The north parcel is approximately 2.63 hectares and had been planted on approximately June $8-13,2011$ by a custom seed applicator from the local area. The north parcel was planted with six different varieties of grasses: Thinopyrum intermedium (intermediate wheatgrass), a variety of Cave-in-Rock switchgrass $(P$. virgatum) known as "Blade" (Blade Energy Crops ${ }^{\circledR}$, Thousand Oaks, CA.), A. gerardii (big bluestem), Schizachyrium scoparium (little bluestem), Bouteloua curtipendula (sideoats grama) and S. nutans (Indian Grass). The southern parcel was approximately 22.26 hectares and was planted in four separate plots of four differing grass blends between June 8 and 13, 2011. Plot 1 is a three grass warm season perennial mix of big bluestem, switchgrass and Indian grass. Plot 2 is solely the "Blade" variety of switchgrass. Plot 3 is a blend of 4 grasses and 6 forbs, as well as two pounds of Indian grass (Quail Unlimited, Albany, GA.). Plot 4 is a diversity mix of 11 grasses and 22 forbs (Pheasants Forever, St. Paul, MN.). During the 2010 growing season, both parcels had been planted in Zea mays (corn). 
We conducted preliminary research on the area by observing aerial / satellite photographs and conducting an on-sight, informal survey with representatives of AWI. Due to an extraordinarily hot summer with little rainfall, the ground appeared to be barren of insect or animal life, save a few mouse/vole holes in the ground. The research area was an early successional community (Harper et al. 2008) growing among the warm season perennial grasses. Very few insects were encountered and one Common Night Hawk (Chordeiles minor) was flushed from the grass. The warm season perennial grasses could be seen growing, but the ground appeared to be overrun with Amaranthus rudis (water hemp), possibly due to improper burn down techniques or the failure to use a smother crop prior to planting (Fiske and Wolfe, 1995).

We observed three distinct grasses had been planted: switchgrass, Indian grass and big bluestem. Rudbeckia hirta (Black-eyed Susan) wildflowers were abundant as they were planted as one of the forbs, as well as Chamaechrista fasiculata (partridge pea). Aside from a few dandelions (Taraxacum officinale), no other plants were readily abundant. We did note from the ground inspection that the planting schematic provided and the ground survey of what was actually planted differed. Using geographic information systems (GIS) available from the Macon County, Illinois Supervisor of Assessments website (http://gis.co.macon.il.us/), we noticed that this parcel of ground is a land locked fragment of environment with no apparent natural travel corridors and the nearest water source being in excess of 2,000 meters away to the south east. As a habitat for anything other than small mammals or birds, it appeared to be unsuitable to sustain life.

\subsection{Monitoring and Inventory of Species}

In the Multiple Species Inventory and Monitoring Technical Guide developed by the United States Department of Agriculture (Manley et al., 2006), it was recommended that eight transects, $200 \mathrm{~m}$ long, be used to trap small mammals. This type of arrangement was not useful for our purposes, since the schematic of the USDA would require a parcel of land that encompassed an area 200 meters long and 200 meters wide, with traps located on transects 20 meters apart. We decided to reduce the trapping site down into an area that was more manageable (i.e., that could be handled by one person in under two hours). The arrangement of traps that we chose to use was in roughly a diamond shape, 50 meters in total length and width, with four tiers or layers of traps that have been staggered in placement at set depths, emanating from one central point. The traps averaged 4 to 5 meters apart, even though in a study of small mammal trapping (Jones et al., 1996), researchers theorized that most small mammal species had a 20 meter radius home range that was travelled and only one trap per 20 meters was needed. We theorized that since some small mammals are social animals, one trap per 20 meters would not be as effective in determining the true population of a given area. Utilizing this trapping method, only one reference point (determined by Global Positioning System) and a compass would be needed in order to conduct subsequent trapping sessions in the same locations. Reference stakes could be removed from the research area in order for the AWI to mow the area.

Since the parcels are broken up into approximately 4 sections apiece by the method in which they were planted, using a standard rotation, we intended to trap in sessions of 3 consecutive nights from September to November, alternating between the northern and southern parcels. We did this to ensure that we never trapped adjoining sections on consecutive rotations to minimize habitat disturbance and since previous studies have shown that $80-85 \%$ of a population will be captured within 3 days (Shenbrot et al., 2010). We used a series of 52 small and medium sized mammal traps to identify vertebrate species occupying the parcels of ground. Forty-eight small Sherman ${ }^{\mathrm{TM}}$ (H.B. Sherman Traps, Inc., Tallahassee, FL.) live traps were used to capture small mammals, as well as four larger Tomahawk ${ }^{\mathrm{TM}}$ (Tomahawk Live Trap Co., Tomahawk, WI.) live traps for medium sized wild or feral mammals. The bait that we used was crushed oats (oatmeal) with shelled peanuts (used for an olfactory component) for small mammals and commercially available salt wheels and canned cat food to lure larger mammals.

\subsection{Data Collection and Analysis}

All animal life captured was measured to the nearest millimeter with a portable ruler, weighed using a 60 gram Pesola ${ }^{\circledR}$ (Pesola AG, Baar, Switzerland) Micro-line 20060 hanging spring scale to the nearest .5 gram, ear tagged (National Band and Tag Company, Newport, KY.) in order to identify repeat captures, photographed and then released on site utilizing scientifically accepted methods and guidelines developed by the American Society of Mammalogists (Sikes et al., 2011). Collection methods and procedures were conducted with the consent of the Illinois Department of Natural Resources and were approved by the Millikin University animal use and care committee. Plant species were identified using Mohlenbrock (2002). All native species were released at the capture site as soon as the data collection was completed to minimize stress due to handling. 


\section{Results}

Within the first year of switching from a corn/soybean agricultural rotation to the production of agricultural bio-mass, a seemingly inhospitable (urban) agricultural area revealed a diverse population of inhabitants. From September to November 2011, we logged 1248 trapping nights, with only 23 trapping nights being unsuccessful. A total of 117 animals were captured during the initial three month trapping session, representing five separate species of small mammals inhabiting the research area: Blarina brevicauda, Peromyscus leucopus, Peromyscus maniculatus, Microtus ochrogaster and Mus musculus (Table 1). Of the 117 mammals that were captured, 83 were first time captures that were subsequently measured, tagged and released. Four mammals were lost prior to tagging and there were 12 fatalities ( 3 new animals and 9 previously captured animals). 100 of the captures were in the south plot; 17 of the captures were in the north plot.

Table 1. Species captured and number of captures by year at Prairie for biodiversity research area, Decatur, Illinois

\begin{tabular}{lllll}
\hline & \multicolumn{5}{l}{ Number of Captures by year } \\
\hline Species & 2011 & 2012 & 2013 & Total \\
Deer mouse (Peromyscus maniculatus) & 57 & 260 & 11 & 328 \\
White footed mouse (Peromyscus lecucopus) & 20 & 0 & 0 & 20 \\
Norway rat (Rattus norvegicus) & 0 & 1 & 0 & 1 \\
Prairie vole (Microtus ochrogaster) & 4 & 8 & 2 & 14 \\
Short tailed shrew (Blarina brevicauda) & 1 & 2 & 1 & 4 \\
House mouse (Mus musculus) & 1 & 0 & 0 & 1 \\
Eastern cottontail (Sylvilagus floridanus) & 0 & 1 & 4 & 5 \\
\hline Total & 83 & 272 & 18 & 373 \\
\hline
\end{tabular}

From September to November 2012, we logged 1196 trapping nights, with only 1 trapping night being unsuccessful. A total of 296 animals were captured during the second three month trapping session, representing five separate species of small mammals inhabiting the research area: B.brevicauda, Rattus norvegicus, P. maniculatus, M. ochrogaster and Sylvilagus floridanus (Table 1). Of the 296 mammals that were captured, 272 were first time captures that were subsequently measured, tagged and released. Seven mammals were lost prior to tagging and there were 31 fatalities (15 new captured animals, 16 previously captured animals); 11 animals were found lying dead near the research area. Of the 272 new captures, 188 of the captures were in the south plot; 84 of the captures were in the north plot.

From September to November 2013, we logged 1144 trapping nights, with 1129 trapping nights being unsuccessful. A total of 18 animals were captured during the final trapping session, representing 4 species previously known to inhabit the research area: M. ochrogaster, P. maniculatus, B. brevicauda and S. floridanus (Table 1). No animals were lost prior to tagging and there were 5 fatalities. Of the 18 animals captured, 17 of the captures were in the north plot and only 1 of the captures was in the south plot.

Peromyscus maniculatus (deer mouse) was the predominant species captured in 2011, 2012, and 2013. P. maniculatus population numbers initially rose from 57 captures to 260 captures in 2012; falling to 11 captures in 2013. Microtus ochrogaster (prairie vole) rose in 2012, then fell in 2013, while Blarina brevicauda (short tailed shrew) populations appeared unchanged, as they were caught in similar numbers all three years of the study. Peromyscus leucopus (white footed mouse), which had been captured 20 times in 2011 was not located or captured during 2012 or 2013. Sylvilagus floridanus (eastern cottontail) appeared in the study area during the second year and was regularly observed and captured. There was a direct correlation between the population increase of $P$. maniculatus and the decline in the population of $P$. leucopus when a Chi-square test was run with $P<0.05$ (Table 2). 
Table 2. Chart of values used to determine if a relationship existed between the population increase of $P$. maniculatus and the decline in population of P. leucopus. (Statistical analysis courtesy C. Watson)

\begin{tabular}{llll}
\hline & DEER MOUSE & WHITE FOOTED MOUSE & TOTAL \\
\hline 2011 & 57 & 20 & 77 \\
2012 & 260 & 0 & 260 \\
TOTAL & 317 & 20 & 337 \\
$\mathrm{X}^{2}$ & 13.02373887 & 4.569732938 & \\
$P$ & $1.04 \mathrm{E}-40$ & $6.71 \mathrm{E}-17$ & \\
\hline
\end{tabular}

\section{Discussion}

Small mammals are generally underrepresented in mammal research (Yarnell et al., 2007). Many studies have been conducted regarding the impact of warm season perennial grasses on game and song birds, however, very few studies have concentrated on the long term impact of biomass agricultural production on small mammals. Since the area was cultivated and planted in the aforementioned manner prior to the start of my research, we have no data regarding former resident birds and mammals that were dependent on the corn / soybean production and that were possibly displaced as a result of the agricultural shift. As a result, it is assumed that the mammal species present when the study began were already represented in the corn / soybean agricultural matrix. This study focuses solely on the mammals residing in our research area at the start of trapping in 2011 through 2013 and the subsequent impact of perennial grass agricultural production on the resident mammals. Trapping nights differed slightly between the 2011 to 2013 trapping periods, simply because as an agricultural production area, traps were removed at times for machinery to enter into the research area to harvest the bioenergy crop.

Due to the harsh environmental conditions during the initial survey of the research area and only early successional growth was present, we began this study with the hypothesis that very few mammals would be located in the research area. Contrary to the hypothesis, in 2011 we captured 290 animals. Our initial hypothesis was not supported.

Between 2011 and 2012, it appeared that the biomass agricultural area was beneficial for small mammals, due to the numbers of mammals captured throughout the research area. In a study conducted in Texas (George, 1985), researchers found switch grass to be a good pheasant nesting cover and stated that more than 60 birds and mammals used the seeds and other plant material for food. In Murray and Best (2003), the researchers theorized that the late autumn / winter harvest would enhance bird reproductive fitness because agricultural activity would not disturb nesting. The initial phase of trapping appeared to support previous research regarding the benefits of warm season perennial grasses to birds, but researchers also found that food availability was terribly low in switchgrass monocultures due to lack of desirable forbs and excessive grass density after 5-6 years (Harper et al., 2008).

In the second year of the study, we hypothesized that with the shift to biomass agriculture, the abundance of seed available for the small mammals would increase the numbers in the population currently present. As the numbers of small mammals increased, eventually, raptors and larger mammalian predators would be attracted to the research area, but that they would not remain due to a lack of water. Without natural predators remaining near the research area to control the population of small mammals, we hypothesized that the small mammals would see an exponential growth over the coming months and years that could have a detrimental effect on the biomass growth due to over consumption of plant material and on the population by increased competition for resources.

In 2012, P. maniculatus was captured 260 times, B. brevicauda was captured 2 times, M. ochrogaster was captured 8 times, Rattus norvegicus (brown rat) was captured 1 time and 1 Sylvilagus floridanus (Eastern cottontail) was captured. Midway through the 2012 trapping season, it became apparent that P. leucopus had disappeared from the research area. We began to look into why P. leucopus would have disappeared. Had the switch to biomass agriculture caused the local extinction of $P$. leucopus? We ran a Chi square test to see if there was any correlation between the disappearance of $P$. leucopus and the increase in $P$. maniculatus. We found a correlation between the absence of $P$. leucopus and the increased population of $P$. maniculatus $(\mathrm{p}<.05)$, suggesting competitive exclusion (Gause, 1934). Even though the data suggested competitive exclusion and subsequent local extinction of $P$. leucopus by $P$. maniculatus, there were several problems with making that statement.

Maron and Pearson (2011) stated that predation could have an impact on numbers in a population. Over the 
2011-2013 research periods, we found scat on one occasion in 2011 from a large mammalian predator. A field examination of the scat revealed bones from unidentified mammals within it, proving that at least one mammalian predator had been on the fringes of the research area. We do not believe that predators had a large impact on population numbers, since there is no readily available ground water to keep them in the research area. This instance of predation was more than likely an isolated nomad travelling through the area.

At the onset of the study, drought conditions overcame the region (and continued into 2013). Disturbance events like natural disasters or severe climatic extremes allow for rapid population shifts and for the establishment of invasive species (Brown, 2011). Due to an absence of available ground water and shelter from the extreme temperatures that season, the drought conditions may have forced P. leucopus to find a habitat that was less harsh and the species may have moved from the study area. This explanation is plausible, but we did not believe that this is the full story.

Kantak (1983) showed that both species of Peromyscus had dietary overlaps, which in our research, could explain the population explosion in P. maniculatus while P. leucopus declined to nothing; again suggesting support for the theory of competitive exclusion. Kantak's study indicated that when mice of both species were paired together, P. maniculatus instead was dominated by P. leucopus; P. maniculatus showed tendencies to avoid contact with $P$. leucopus and $P$. leucopus was the prevailing species in overall competition. P. leucopus tended to be the mouse to display territoriality over $P$. maniculatus and for the theory of competitive exclusion to be valid, $P$. maniculatus would have had to have shown the propensity to dominate over P. leucopus. It did not. This theory was refuted.

In the study by Kantak (1983), it was observed that P. leucopus does not choose to eat seed from Sorghastrum nutans (Indian grass) or Andropogon gerardii (Big Bluestem), both of which are in abundance at the research area. Kantak used mice taken both from old fields and from prairies. In her study, Kantak observed that when $P$. leucopus and P. maniculatus were given the choice, they preferred to eat old field grass seeds over those of prairie grasses, so much so, that the amount of prairie grass seeds eaten was recorded as negligible (Kantak, 1983). Kantak observed that $P$. leucopus, rather than eating prairie grasses, preferred eating old crop grasses such as Elymus repens (quack grass) and Setaria faberi (giant foxtail), as well as forbs. All mice (P. leucopus and P. maniculatus) used in the Kantak study, no matter where they originated, preferred the old field grass seeds. At our research area, $P$. leucopus could have emigrated from the research area as a result of food resources becoming unpalatable, but this explanation does not appear to be supported. Since both $P$. leucopus and $P$. maniculatus appear to utilize the same resources (Kantak, 1983), we should have observed a marked decrease in the numbers of $P$. maniculatus as well; we observed the opposite. Numbers of $P$. maniculatus increased substantially between 2011 and 2012. This explanation was also refuted.

An observation that we had early on was the association between the captured mice and A. rudis (water hemp). It appeared that the mice were utilizing the bases of the water hemp plants as entrances to their burrows, since the ground around the large water hemp plants was split open due to the drought conditions and in other locations of the research area, the ground was hard and smooth (compacted). In DeJaco and Batzli (2013), the authors also do a detailed study of the prominent plants eaten by white footed mice and deer mice, as well as meadow voles and eastern cottontail rabbits, all of which I have captured in my study. Specifically of interest is the fact that white footed mice were found to eat water hemp readily in this study (DeJaco \& Batzli, 2013).

The plant composition in the research area changed dramatically over the 3 year trapping period. In the first year of the study, the research area was primarily occupied by warm season perennial grasses, old field grasses, forbs, and $A$. rudis. The vegetation initially was sparse, with only about 50 percent coverage of the available ground. Within five months of planting, the warm season perennial grasses had obtained a height similar to that of the established A. rudis. In November 2011, the City of Decatur, Illinois threatened CAT with an "Ordinance Violation for Grass and Weeds" due to citizen complaints regarding the research area's unkempt appearance and a lack of knowledge regarding the aims of the research. To prevent civil penalties, CAT had a local farmer come to the research area and mow the plots to a height of $30 \mathrm{~cm}$. What this did in effect was remove the availability of seeds from $A$. rudis that the mammals had been using for food; the warm season perennial grasses were cut prior to dropping seeds and all of the herbaceous material in the research area was now on an even footing.

By the second year of the study, the research area had become dominated by warm season perennial grasses and A. rudis, but still had a diverse mixture of forbs in sections with approximately 75 to 80 percent of the ground covered in vegetation. By the third year of the study (2013), the warm season perennial grasses now dominated $95(+)$ percent of the landscape in a thick monoculture with few forbs around the perimeter of the grass fields. No bare ground was visible and the grasses had thickened to a near impenetrable jungle more than two meters in 
height. A. rudis had become choked out by the perennial grasses and was absent from the research area.

In 2013, P. maniculatus captures dropped to 11, S. floridanus was captured 4 times, B. brevicauda was captured 1 time and M. Ochrogaster was captured 2 times. It is a possibility that the absence of water hemp from the research area in 2013 is a direct cause of the noticeable absence of $P$. maniculatus. In the early successional field, A. rudis had become a pulsed resource (Marcello et al., 2008, Pedersen et al., 2008) which had caused a population explosion in both P. leucopus and P. maniculatus. Being the dominant species, P. leucopus had obtained control of the source habitat of the research area, relegating $P$. maniculatus to the sink habitat areas of the fields. Due to low instances of predation and a greater quantity of sink habitat that was not low in quality overall, the numbers of $P$. maniculatus increased at a far greater rate than those of $P$. leucopus (Schreiber \& Kelton, 2005). As the density of the perennial grasses increased, the source habitat occupied by $P$. leucopus became sink habitat as well. As a result of habitat becoming unfavorable, resources becoming limited, and $P$. maniculatus densities being higher than $P$. leucopus could push out, the shifting agricultural mosaic caused the local extinction of $P$. leucopus.

As the warm season perennial grasses entered their third year of growth, the fields became an impenetrable jungle, choking the old field grasses and forbs out of the landscape. At the onset of the study, drought conditions overcame the region and continued into 2013. Shenbrot et al. (2010) found that rodent densities in most cases were positively correlated with total precipitation during the previous rainy season and stochastic models produced by Reed et al. (2007) predicted a marked decrease in population growth rate as the frequency of dry years increased. After two seasons that would have had a positive impact on reproduction in P. maniculatus due to an increase in food resources, a population crash occurred. In order to stabilize the population, there had to have been a higher death rate than birth rate among some age groups (Boonstra et al., 1998). Due to a cascade of effects (Smith, 2010) occurring at our research site (a high death rate in the breeding cohort, the $3^{\text {rd }}$ year of drought conditions and a reduction in habitat and resources), P. maniculatus population numbers could not be sustained and the population crashed. Our secondary hypothesis was partially supported.

\section{Conclusion}

Warm season perennial grass agriculture is a third year crop. Early successional habitat in our research area was shown to be beneficial temporarily for wildlife, but upon the warm season perennial grasses reaching maturity during the second and third years, the resulting monoculture became unfavorable and unpalatable for some mammals in our research area. It is our position that CRP acreage being converted into biomass agriculture should be designed as a mixture of short and tall warm season perennial grasses, as well as forbs to maximize their benefits to the ecosystem. By utilizing a variety of plants, structure for wildlife can be provided, soil can be stabilized in marginal land areas to limit the erosion of soil and field runoff, food resources for wildlife can be maintained and the overall heterogeneity of the ecosystem can be improved.

\section{Acknowledgements}

We would like to thank Dr. Judith A. Parrish, The Agricultural Research Institute, Caterpillar, Inc., the Illinois Department of Natural Resources and Millikin University for the opportunity to conduct this research. I would also like to thank Dr. Casey Watson and Dr. Travis Wilcoxen for their support, assistance with statistics and guidance during the course of this study. I would like to especially thank my wife Mary Leimbach for her support and children, David J. and Kendall S. Leimbach, for their assistance with checking traps, recording data and hauling equipment.

\section{References}

Batie, S. S. (2009). Green payments and the US Farm Bill: information and policy challenges. Frontiers in Ecology and the Environment, 7, 380-388. http://dx.doi.org/10.1890/080004

Boonstra, R., Krebs, C. J., \& Stenseth, N. C. (1998). Population cycles in small mammals: the problem of $\begin{array}{lllll}\text { explaining the low } & \text { Ecology, } & 79(5), & 1479-1488 .\end{array}$ http://dx.doi.org/10.1890/0012-9658(1998)079\%5B1479:PCISMT\%5D2.0.CO;2

Brown, L. R. (2011). Eroding Futures: Why healthy soil matters to civilization. Futurist, 45, 23-30.

DeJaco, C. E., \& Batzli, G. O. (2013). Palatability of plants to small mammals in nonnative grasslands of east -central Illinois. Journal of Mammalogy, 94, 427-435. http://dx.doi.org/10.1644/12-MAMM-A-157.1

Fiske, D. A., \& Wolf, D. (1995). Planting and managing switch grass for forage, wildlife and conservation. Virginia Cooperative Extension, 418-013.

Gause, G. F. (1934). The struggle for existence. Williams and Wilkins, Baltimore, MD, United States of America. http://dx.doi.org/10.5962/bhl.title.4489 
George, R. R. (1985). Reseeding pastures and rangeland for wildlife benefits in the central and southern Great Plains. Iowa Wildlife Research Bulletin (1st ed.). 37B-42B.

Harper, C.A., Moorman, C. E., \& Keyser, P. D. (2008). Native warm-season grasses and early successional wildlife habitat: past lessons and a new vision. Proceedings Eastern Native Grass Symposium, 6, 120-126.

Hartman, J. C., Nippert, J. B., Orozco, R. A., \& Springer, C. J. (2011). Potential ecological impacts of switch grass (Panicum virgatum L.) biofuel cultivation in the Central Plains, USA. Biomass and Bioenergy, 35, 3415-3421. http://dx.doi.org/10.1016/j.biombioe.2011.04.055

John, S., \& Watson, A. (2007). Establishing a grass energy crop market in the Decatur area (1st ed.). Decatur, IL: The Agricultural Watershed Institute.

Jones, C., McShae, W. J., Conroy, M. J., \& Dunz, T. H. (1996). Capturing mammals. In D. E. Wilson, F. R. Cole \& J. D. Nichols (Eds.). Measuring and monitoring biological diversity: standard methods for mammals (pp. 115-155). Washington, DC, United States of America: Smithsonian Institution Press.

Kantak, G. E. (1983). Behavioral, seed preference and habitat selection experiments with two sympatric Peromyscus Species. American Midland Naturalist, 109, 246-252. http://dx.doi.org/10.2307/2425404

Manley, P. M., Van Horne, B., Roth, J. K., Zielinski, W. J., McKenzie, M. M., WELLER, T. J., ... Vojta, C. (2006). Multiple Species Inventory and Monitoring Technical Guide: Version 1.0. United States Department of Agriculture. Print.

Marcello, G. J., Wilder, S. M., \& Meikle, D. B. (2008). Population dynamics of a generalist rodent to variability in pulsed food resources in a fragmented landscape. Journal of Animal Ecology, 77, 41-46. http://dx.doi.org/10.1111/j.1365-2656.2007.01310.x

Maron, J. L., \& Pearson, D. E. (2011). Vertebrate predators have minimal cascading indirect effects on plant production in an intact grassland ecosystem. Ecology Letters, 14, 661-669. http://dx.doi.org/10.1111/j.1461-0248.2011.01633.x

Mohlenbrock, R. H. (2002). Vascular flora of Illinois: A field guide (3rd ed.). Southern Illinois University: Carbondale, Illinois, United States of America.

Murray, L. D., Best, L. B., Jacobsen, T. J., \& Braster, M. L. (2003). Potential effects on grassland birds of converting marginal cropland to switchgrass biomass production. Biomass and Bioenergy, 25, 167-175. http://dx.doi.org/ 10.1016/S0961-9534(02)00187-3

Pedersen, A. B., \& Grieves, T. J. (2008). The interaction of parasites and resources cause crashes in a wild mouse population. Journal of Animal Ecology, 77, 370-377. http://dx.doi.org/10.1111/j.1365-2656.2007.01321.x

Reed, A.W., Kaufman, G. A., \& Sandercock, B. K. (2007). Demographic response of a grassland rodent to $\begin{array}{lllll}\text { environmental variability. Journal of Mammalogy, } & \text { 88, }\end{array}$ http://dx.doi.org/10.1644/06-MAMM-A-109R.1

Ryan, M. B., \& Marks, R. (2005). Native warm season grasses and wildlife. United States Department of Agriculture, Natural Resources Conservation Service Leaflet Number, 25, 1-8.

Schreiber, S. J., \& Kelton, M. (2005). Sink habitats can alter ecological outcomes for competing species. Journal of Animal Ecology, 74, 995-1004. http://dx.doi.org/10.1111/j.1365-2656.2005.00996.x

Shenbrot, G., Krasnov, B., \& Burdelov, S. (2010). Long-term study of population dynamics and habitat selection of rodents in the Negev Desert. Journal of Mammalogy, 91, 776-786. http://dx.doi.org/10.1644/10-MAMM-S-154.1

Sikes, R. S., Gannon, W. L., and the Animal Care and Use Committee of the American Society of Mammalogists. (2011). Guidelines of the American Society of Mammalogists for the use of wild mammals in research. Journal of Mammalogy, 92, 235-253. http://dx.doi.org/ 10.1644/10-MAMM-F-355.1

Smith, F. S. (2010). Texas today: A sea of the wrong grasses. Ecological Restoration, 28, 112-117. http://dx.doi.org/10.3368/er.28.2.112

Yarnell, R. W., Scott, D. M., Chimimba, C. T., \& Metcalfe, D. J. (2007). Untangling the roles of fire, grazing and rainfall on small mammal communities in grassland ecosystems. Oecologia, 154, 387-402. http://dx.doi.org/10.1007/s00442-007-0841-9

\section{Copyrights}

Copyright for this article is retained by the author(s), with first publication rights granted to the journal.

This is an open-access article distributed under the terms and conditions of the Creative Commons Attribution license (http://creativecommons.org/licenses/by/3.0/). 